\title{
Fouling and gastropod predation: consequences of grazing for a tropical octocoral
}

\author{
Donald J. Gerhart \\ Duke University Marine Laboratory, Pivers Island, Beaufort, North Carolina 28516, USA
}

\begin{abstract}
The ovulid gastropod Cyphoma gibbosum Linnaeus is a specialist consumer of gorgonian octocorals. Although the direct effects of its feeding do not appear to be great, the indirect consequences may be substantial. An $8 \mathrm{wk}$ study of the gorgonian Plexaura homomalla Esper in Curaçao found that $C$. gibbosum occurred primarily on the lower $30 \mathrm{~cm}$ of colonies, and that there were significant correlations between $C$. gibbosum density and the extent of colony fouling on the lower $30 \mathrm{~cm}$ of colonies. This correlation occurred whether one measured initial fouling, final fouling, or change in fouling during the 8 wk. There were no significant correlations of $C$. gibbosum density and fouling for colony portions more than $30 \mathrm{~cm}$ above the holdfast. These findings and direct observations in the field suggest that feeding by $C$. gibbosum increases fouling of gorgonians by exposing the axial skeleton and providing settling sites for fouling propagules. Because fecundity of $P$. homomalla is reduced when fouling separates colonies into a series of smaller aggregates, the indirect effects of $C$. gibbosum grazing could strongly affect the fitness of $P$. homomalla and other gorgonians.
\end{abstract}

\section{INTRODUCTION}

Octocorals (Coelenterata: Anthozoa: Octocorallia) are abundant on coral reefs throughout the tropical Indo-Pacific and western Atlantic. The gorgonian octocorals (Gorgonacea), popularly known as sea fans and sea whips, are particularly common on shallow reefs in the Caribbean Sea, the Florida Keys, USA, and Bermuda (Bayer 1961, Kinzie 1973).

Gorgonian octocorals are consumed by few predators. Randall (1967) noted that gorgonian tissue was absent from the gut contents of most reef fishes. Bakus (1981) demonstrated that most gorgonians and other conspicuous, sessile reef invertebrates contained extractable substances that were toxic to fish. Recent experiments have shown that the calcium carbonate sclerites and secondary metabolites of some gorgonians can deter fish feeding (Gerhart 1984, Pawlik et al. 1987, Gerhart et al. 1988, Harvell et al. 1988, Harvell \& Fenical 1989).

In spite of these defenses, several species of ovulid gastropods readily consume gorgonians (Kinzie 1970 . Patton 1972, Lasker \& Coffroth 1988, Lasker et al. 1988). In the tropical western Atlantic, one of these gastropods, Cyphoma gibbosum (the 'Flamingo Tongue snail'), frequents shallow reefs and feeds exclusively on gorgonians (Kinzie 1970). C. gibbosum consumes with- out ill effect even those gorgonian species that contain high concentrations of sclerites or toxic secondary metabolites (Kinzie 1970, Hazlett \& Bach 1982, Gerhart 1986, Harvell \& Suchanek 1987, Harvell \& Fenical 1989).

Cyphoma gibbosum rarely kills its hosts (Kinzie 1970 , Birkeland \& Gregory 1975), and damaged gorgonians can regenerate their lost tissues (Silveira \& Van't Hof 1977). However, grazing by C. gibbosum may increase gorgonian fouling. A number of authors have observed that uninjured gorgonian tissue is rarely overgrown by epibionts (Burkholder 1973, Targett et al. 1983, Standing et al. 1984, Rittschof et al. 1985, Gerhart 1989, Davis et al. in press). It has been suggested that exposure of the axial skeleton by physical abrasion or predation can allow the settlement of epibionts, and that this fouling may decrease the fecundity (Wahle 1983a) and increase the mortality of gorgonians (Kinzie 1974, Silveira \& Van't Hof 1977, Wahle 1980, Wahle 1985).

Although the relationship between predation and gorgonian fouling has important implications for gorgonian ecology and evolution, this relationship has not been systematically examined or quantified. Therefore, the goals of this study were: (1) to examine systematically the association of predation by Cyphoma gibbosum and fouling of the gorgonian Plexaura homomalla; (2) to 
quantify the degree of correlation between these factors; and (3) to observe the sequence of events that linked gorgonian fouling to gastropod predation.

\section{METHODS}

Study site. The study was performed at Kaap Malmeeuw, Curaçao, Netherlands Antilles. This area has been described in detail by Hoek et al. (1978). Cyphoma gibbosum Linnaeus in this location predominately occupy the lower $30 \mathrm{~cm}$ of Plexaura homomalla Esper colonies (Gerhart 1989).

Field methods. Fifty-four colonies of Plexaura homomalla were marked with plastic tags, ranged in depth from 6 to $11 \mathrm{~m}$, and varied in height from 19 to $110 \mathrm{~cm}$. Colonies were examined 4 to $5 \mathrm{~d} \mathrm{wk}^{-1}$ for $8 \mathrm{wk}$. During each observation, the number of Cyphoma gibbosum occupying each colony was recorded, and the distance from the colony holdfast to each gastropod measured. Colony size was quantified by measuring the maximum height of each gorgonian. Measurements of fouling were made at the beginning and end of the study period. The amount of fouling on each colony was quantified by measuring, to the nearest $0.5 \mathrm{~cm}$, the linear dimension of fouled sections of axial skeleton. The total amount of fouling for each colony was then expressed as the sum of the lengths of the fouled sections.

Statistical analyses. All statistical tests were performed as described by Sokal \& Rohlf (1981). Correlation coefficients were calculated between the initial level of fouling and the initial number of gastropods occupying the colony, between the final amount of fouling and the average number of Cyphoma gibbosum per colony, and between the change in fouling during the study interval and the average number of C. gibbosum per colony. The statistical significance of changes in the amount of fouling on snail-occupied, unoccupied, and fouled but unoccupied colonies was determined by Wilcoxon's signed ranks test. Fouling on low $(<30 \mathrm{~cm}$ from the holdfast) versus high ( $>30 \mathrm{~cm}$ from the holdfast) sections of gorgonians were compared using Student's t-test.

\section{RESULTS}

\section{Intra-colony distribution of fouling and gastropods}

During the study $96 \%$ (1000 of 1038) of Cyphoma gibbosum observation were of gastropods occupying the lower $30 \mathrm{~cm}$ of marked Plexaura homomalla colonies (Table 1). The mean height of these marked colonies was $60.3 \mathrm{~cm}(\mathrm{n}=54, \mathrm{SE}=2.72 \mathrm{~cm}$ ), and more than $90 \%$ of the colonies were greater than $30 \mathrm{~cm}$ in height. Thus, $C$. gibbosum tended to occupy the lower sections of $P$. homomalla at this study site (see also Gerhart 1989).
Table 1. Plexaura homomalla. Intra-colony distribution of fouling on marked gorgonian colonies. Fouling and occupancy by Cyphoma gibbosum were concentrated on the lower sections of colonies. Average fouling levels (and SE in parentheses) are based on measurements of 54 colonies. See text for statistical tests and significance levels

\begin{tabular}{|lcc|}
\hline & $\begin{array}{c}\text { Intra-colony location (all colonies): } \\
<30 \mathrm{~cm} \\
\text { above holdfast }\end{array}$ & $\begin{array}{c}>30 \mathrm{~cm} \\
\text { above holdfast }\end{array}$ \\
\hline $\begin{array}{l}\text { No. observations of } \\
\text { Cyphoma gibbosum } \\
\text { colony-days) }\end{array}$ & $1000(96 \%)$ & $38(4 \%)$ \\
$\begin{array}{l}\text { Average fouling (cm) } \\
\text { At inception } \\
\text { At completion }\end{array}$ & $16.0(0.5)$ & $0.7(0.2)$ \\
Change in fouling & $23.2(5.8)$ & $0.2(0.02)$ \\
& $+7.2(2.5)$ & $-0.5(0.3)$ \\
\hline
\end{tabular}

At both the inception and completion of the study, colony fouling was greater in lower sections of the gorgonians than in higher sections of the colonies (Table $1 ; \mathrm{n}=54$ colonies; Wilcoxon's signed ranks test, $\mathrm{T}_{\mathrm{s}}=5.6$ for the comparison of fouling at the inception of the study, and 6.3 at the completion of the study; both tests significant with $p<0.001$ ) (Fig. 1). Thus, fouling was greater in the sections of Plexaura homomalla that were most heavily occupied by Cyphoma gibbosum.

\section{Inter-colony distribution of fouling and gastropods}

For colony sections less than $30 \mathrm{~cm}$ from the holdfast, the initial amount of fouling, the final amount of fouling, and the change in fouling (Table 2) were greater on gastropod-occupied colonies than on unoccupied colonies (Student's t-test; $\mathrm{n}_{1}=22$ snail-occupied colonies, $\mathrm{n}_{2}=32$ unoccupied colonies; $\mathrm{p}<0.05$ for all 3 tests). Fouling less than $30 \mathrm{~cm}$ from the holdfast increased significantly during the study on colonies occupied by

Table 2. Plexaura homomalla. Intra-colony distribution of fouling less than $30 \mathrm{~cm}$ from the holdfast on marked colonies. For these lower sections of colonies, the average level (with SEs in parentheses) of fouling and the increase in fouling were significantly higher on gorgonians that had been occupied by Cyphoma gibbosum. See text for statistical tests and significance levels

\begin{tabular}{|lrrrr|}
\hline & $\begin{array}{c}\text { Fouling }(<30 \mathrm{~cm} \text { from colony holdfast }) \\
\text { Snail-occupied } \\
\text { colonies }\end{array}$ & $\begin{array}{c}\text { Unoccupied } \\
\text { colonies }\end{array}$ \\
\hline Average fouling $(\mathrm{cm})$ & & & & \\
At inception & 29.5 & $(7.8)$ & 6.7 & $(1.6)$ \\
At completion & 46.7 & $(12.5)$ & 7.0 & $(1.6)$ \\
Change in fouling & 17.2 & $(5.5)$ & 0.3 & $(0.8)$ \\
\hline
\end{tabular}




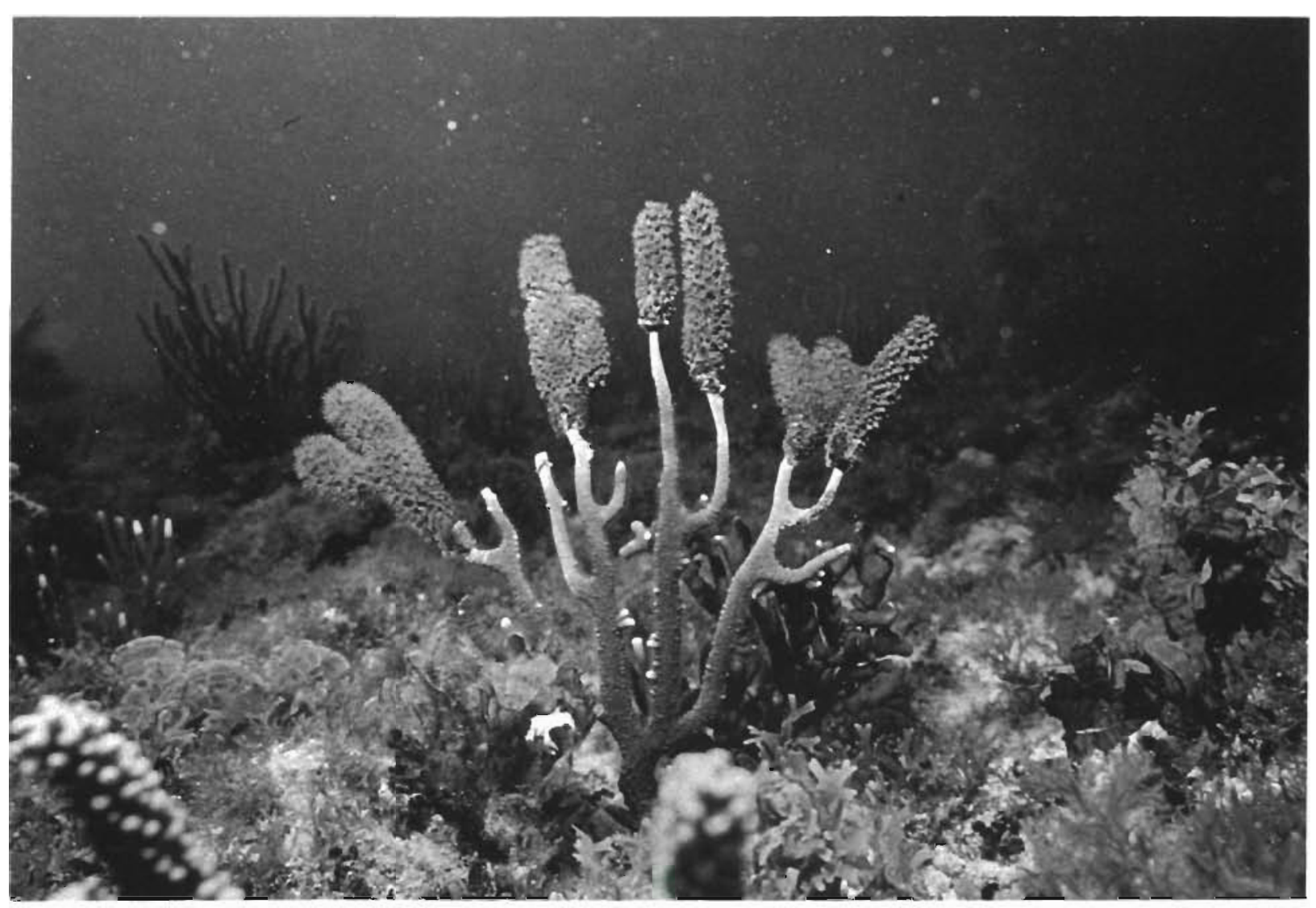

Fig. 1. Plexaura homomalla. Gorgonian colony partially overgrown by firecoral (Millepora complanata). Overgrowth of lower sections of colonies isolates upper branches into sub-colonies. (Photograph by Dr John Halas, Florida Dept of Natural Resources)

gastropods (Wilcoxon's signed ranks test; $\mathrm{p}<0.005 ; \mathrm{n}=$ 22 colonies), but not on unoccupied colonies (Wilcoxon's signed ranks test; $\mathrm{p}>0.05 ; \mathrm{n}=32$ colonies). The amount of fouling below $30 \mathrm{~cm}$ also did not increase significantly on colonies that were not occupied by gastropods, but which were fouled at the beginning of the study (Wilcoxon's signed ranks test; $\mathrm{p}>0.05 ; \mathrm{n}=20$ colonies). Thus, levels of fouling and the increase in fouling were greater on the colonies of Plexaura homomalla that were occupied by Cyphoma gibbosum (Fig. 1).

\section{Correlation of gastropod occupation and fouling}

The initial amount of fouling less than $30 \mathrm{~cm}$ from the holdfast was significantly correlated with the initial number of gastropods occupying the colony $\left(r_{\mathrm{s}}=0.69\right.$; $\mathrm{p}<0.01 ; \mathrm{n}=54$ colonies; Fig. 2A). Furthermore, in this section of the colonies, both the final level of fouling (Fig. 2B) and the change in fouling (Fig. 2C) were significantly correlated with the average number of gastropods occupying the colony $\left(r_{s}=0.71\right.$ and 0.74 , respectively; $n=54$ and $p<0.01$ in both cases). In contrast, for colony sections more than $30 \mathrm{~cm}$ from the colony holdfast, occupation by Cyphoma gibbosum was not correlated with initial fouling, final fouling, or change in fouling of the colonies ( $p>0.05$ in all cases). For fouled colonies, the degree of fouling was not significantly correlated with colony size $\left(\mathrm{r}_{\mathrm{s}}=-0.08\right.$; $p>0.05 ; n=35$ colonies).

It could be argued that these correlations were driven entirely by the low amounts of fouling on colonies that were unoccupied by snails. To eliminate this possibility, the correlation coefficients were re-calculated using only data for the 22 colonies that were occupied at least once by Cyphoma gibbosum during the study period. For these occupied colonies, the correlation between initial fouling and the average number of snails per day was $0.48(\mathrm{n}=22$ colonies, $\mathrm{p}<0.05)$. The correlation between final fouling and the average number of snails per day was 0.60 ( $n=22$ colonies, $p<0.01)$. The correlation between the change in fouling and the average snail occupation was $0.66(n=22$ colonies, $\mathrm{p}<0.01)$. Thus, fouling remained significantly correlated with the average rate of snail occupation, even considering only those colonies that were occupied by snails. 

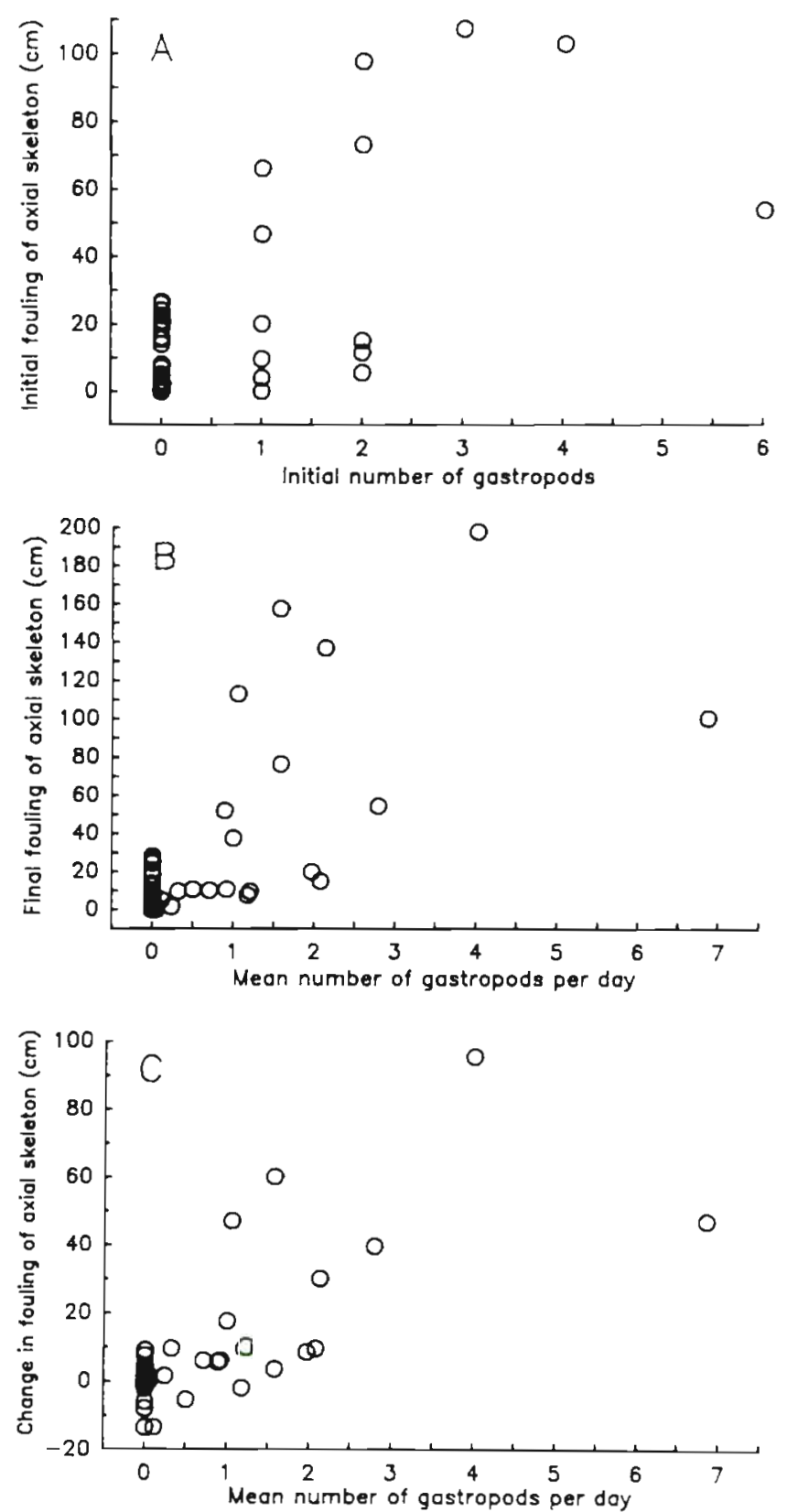

Fig. 2. Plexaura homomalla. Fouling ( $\mathrm{Y}$ axis) and occupation by Cyphoma gibbosum ( $\mathrm{X}$ axis) of marked gorgonian colonies. Data are for the lower sections ( $<30 \mathrm{~cm}$ from the holdfast) of colonies. Colony fouling at inception of study $\left(r_{s}=0.69\right)$. Fouling at the completion of the study $\left(\mathrm{r}_{\mathrm{s}}=0.71\right)$. Change in degree of fouling colony during the study period $\left(r_{s}=0.74\right)$

\section{Observations of predation and fouling}

Feeding scars appeared in colony areas that were occupied by Cyphoma gibbosum, indicating that occupation reflected gastropod predation. (Furthermore, at this and other sites in Curaçao, fouled scars on a gorgonian usually indicated the presence of C. gibbosum.) For example, during the study $C$. gibbosum stripped the coenenchyme from a $9.5 \mathrm{~cm}$ long branch of marked Colony 15 , exposing the axial skeleton. This section of the colony was subsequently colonized and overgrown by fouling organisms. A similar sequence of events was observed for other colonies. This sequence of events was not observed for ungrazed colonies with undamaged tissue, or for sections of snail-occupied colonies that were not occupied by $C$. gibbosum.

\section{DISCUSSION}

Fouling of Plexaura homomalla was significantly correlated with the average number of Cyphoma gibbosum that occupied the colony. Both fouling and gastropod predation were concentrated on the lower sections of colonies. In addition, gorgonian colonies that were occupied by $C$. gibbosum became increasingly fouled during the study; colonies without gastropods did not. Therefore, gastropod predation was correlated not only with the amount of fouling, but was also associated with its distribution and increase.

It could be argued that Cyphoma gibbosum favors large colonies, or that larger colonies are occupied by more gastropods, or that large colonies were more heavily fouled due to their larger size and greater age. If so, then fouling should be positively correlated with colony size. The correlation between colony size and fouling, however, was not significant, and explained only $0.6 \%$ of the variation in fouling between gorgonian colonies.

It could also be argued that the correlations documented in this study do not reflect a causal relationship between gastropod predation and fouling, but rather reflect a preference of Cyphoma gibbosum for gorgonian colonies that, for unknown reasons, also tend to become fouled through time. Manipulative field experiments would help resolve this point. At present, the strongest evidence for a cause-and-effect relationship is supplied by the direct observation of a sequence of events relating predation to fouling. In situ observations indicate that predation by $C$. gibbosum produced tissue loss from the axial skeleton of the gorgonian, and that the bared axial skeleton was subsequently colonized by fouling organisms. Undamaged gorgonians did not become increasingly fouled during the study interval. Furthermore, fouled colonies with gastropods became increasingly overgrown as grazing continued. while fouled colonies without gastropods did not. These observations suggest that the association of gastropod predation and fouling reflects a cause-andeffect relationship, and not a spurious correlation between the 2 variables.

The fouling of gorgonian colonies due to Cyphoma gibbosum grazing may significantly decrease colony 
fecundity. Wahle (1983b) reported that the fecundity of Plexaura homomalla was reduced by injuries that separated the colony into a series of isolates. Damage of this type can be particularly significant in high-energy physical environments, where residence times of $C$. gibbosum are extended and damage is restricted to lower sections of colonies (Gerhart 1989). If fouling does indeed lead to decreased colony fecundity, then natural selection should favor the evolution of gorgonian characters that decrease the frequency or severity of wounding by $C$. gibbosum.

Feeding scars produced by Cyphoma gibbosum are readily visible from a distance, and provide cues that could signal the presence of gastropods to visuallyoriented predators. The mantle of C gibbosum, however, is distasteful to fish, and the conspicuous coloration of this gastropod may serve an aposematic function. (Gerhart 1985, 1986). Thus, the unpalatability of $C$. gibbosum may permit higher grazing rates in this marine gastropod.

Cyphoma gibbosum and other predators that graze upon gorgonians may affect the community structure of coral reefs by opening substrata for larval settlement. Gorgonians appear to serve as refuges against predation for palatable algae (Littler et al. 1987) and invertebrates (Patton 1972, Gerhart et al. 1988). As C. gibbosum feeds, it exposes the axial skeleton of Plexaura homomalla and other gorgonian species (Silveira \& Van't Hof 1977, Harvell \& Suchanek 1987). The exposed axial skeleton offers unoccupied hard substrate that can be colonized by algae and other organisms. Therefore, predation by $C$. gibbosum on gorgonian octocorals may contribute to the maintenance of coral reef diversity by opening refuges from predation for palatable organisms.

Acknowledgements. I thank the government of Curaçao and the staff of the Caribbean Marine Biological Institute (CAR$\mathrm{MABI}$ ) for their assistance during this study, and O. Frans, A. Teil, and $F$. Isabella for their handling and maintenance of research boats. C. J. F. Mangano provided expert field assistance throughout the investigation. Dan Rittschof, Frances White, and 3 anonymous reviewers read initial versions of the manuscript and provided many useful suggestions. Helen Nearing provided expert secretarial assistance. Funding was supplied by the National Science Foundation, Sigma Xi, the American Museum of Natural History, and the National Academy of Sciences

\section{LITERATURE CITED}

Bakus, G. J. (1981). Chemical defense mechanisms on the Great Barrier Reef, Australia. Science 211: 497-499

Bayer, F. M. (1961). The shallow-water Octocorallia of the West Indian region. (Studies on the Fauna of Curaçao and other Caribbean Islands, No. 55.) Martinus Nijhoff, The Hague Birkeland, C., Gregory, B. (1975). Foraging behavior and rates of feeding of the gastropod Cyphoma gibbosum. Sci. Bull, nat. Hist. Mus. Los Ang. Cty 20:57-67

Burkholder, P. R. (1973). The ecology of marine antibiotics and coral reefs. In: Jones, O. A., Endean, R. (ed.) The biology and geology of coral reefs, Vol. II, Biology I. Academic Press, New York, p. 117-182

Davis, A. R., Targett, N. M., McConnell, O. J., Young, C. M. (1989). Epibiosis of marine algae and benthic invertebrates: natural products chemistry and other mechanisms inhibiting settlement and overgrowth. In: Scheuer, P. J. (ed.) Bioorganic marine chemistry, Vol. III. Springer-Verlag, New York, p. 86-114

Gerhart, D. J. (1984). Prostaglandin $A_{2}$ : an agent of chemical defense in the Caribbean gorgonian Plexaura homomalla. Mar. Ecol. Prog. Ser. 19: 181-187

Gerhart, D. J. (1985). Chemical ecology on the coral reef: prostaglandins in the gorgonian Plexaura homomalla. Proc. 5th int. Coral Reef Cong., Tahiti 6:57-62

Gerhart, D. J. (1986). Gregariousness in the gorgonian-eating gastropod Cyphoma gibbosum: tests of several possible causes. Mar. Ecol. Prog. Ser. 31: 255-263

Gerhart, D. J. (1989). Movements of the tropical gorgonianeating gastropod Cyphoma gibbosum (Linnaeus): association with wave surge. Mar behav. Physiol. 15: 207-215

Gerhart, D. J., Rittschof, D., Mayo, S. W. (1988). Chemical ecology and the search for marine antifoulants: studies of a predator-prey symbiosis. J. chem. Ecol. 14: 1905-1917

Harvell, C. D., Fenical, W. (1989). Chemical and structural defenses of Caribbean gorgonians (Pseudopterogorgia spp.): intracolony localization of defense. Limnol. Oceanogr. 34: 382-389

Harvell, C. D., Fenical, W., Greene, C. H. (1988). Chemical and structural defenses of Caribbean gorgonians (Pseudopterogorgia spp.). I. Development of an in situ feeding assay. Mar. Ecol. Prog. Ser. 49: 287-294

Harvell, C. D., Suchanek, T H. (1987). Partial predation on tropical gorgonians by Cyphoma gibbosum (Gastropoda). Mar. Ecol. Prog. Ser. 38: 37-44

Hazlett, B. A., Bach, C. E. (1982). Distribution pattern of the flamingo tongue shell (Cyphoma gibbosum) on its gorgonian prey (Briareum asbestinum). Mar behav. Physiol. 8: $305-309$

Hoek, C. van den, Breeman, A. M., Bak, R. P. M., Buurt, G. van (1978). The distribution of algae, corals, and gorgonians in relation to depth, light attenuation, water movement, and grazing pressure in the fringing coral reef of Curaçao, Netherlands Antilles. Aquat. Bot. 5: 1-46

Kinzie, R. A. (1970). The ecology of the gorgonians (Cnidaria, Octocorallia) of Discovery Bay, Jamaica. Doctoral dissertation, Yale University, New Haven, Connecticut

Kinzie, R. A. (1973). The zonation of West Indian gorgonians. Bull. mar. Sci. 23: 93-155

Kinzie, R. A. (1974). Plexaura homomalla: the biology of a harvestable marine resource. Stud. trop. Oceanogr., Miami 12: $22-38$

Lasker, H. R., Coffroth, M. A. (1988). Temporal and spatial variability among grazers: variability in the distribution of the gastropod Cyphoma gibbosum on octocorals. Mar. Ecol. Prog. Ser. 43: 285-295

Lasker, H. R., Coffroth, M. A., Fitzgerald, L. M. (1988). Foraging patterns of Cyphoma gibbosum on octocorals: the roles of host choice and feeding preference. Biol. Bull. mar. biol. Lab., Woods Hole 174: 254-266

Littler, M. M., Littler, D. S., Taylor, P. R. (1987). Animal-plant defense associations: effects on the distribution and abundance of tropical reef macrophytes. J. exp. mar. Biol. Ecol. 105: $107-122$ 
Patton, W. K. (1972). Studies on the animal symbionts of the gorgonian coral Leptogorgia virgulata (Lamarck). Bull. mar Sci. 22: 419-431

Pawlik, J. R., Burch, M. T., Fenical, W (1987). Patterns of chemical defense among Caribbean gorgonian corals: a preliminary survey. J. exp. mar. Biol. Ecol. 108: 55-66

Randall, J. E. (1967). Food habits of reef fishes of the West Indies. Stud, trop. Oceanogr., Miami 5: 665-847

Rittschof, D., Hooper, I. R., Branscomb, E. S., Costlow, J. D. (1985). Inhibition of barnacle settlement and behavior by natural products from whip corals, Leptogorgia virgulata (Lamarck, 1815). J. chem. Ecol. 11: 551-563

Silveira, F. Lang da, Van't Hof, T. (1977). Regeneration in the gorgonian Plexaura flexuosa (Cnidaria, Octocorallia). Bijdr. Dierk. 47: 98-108

Sokal, R. R., Rohif, F. J. (1981). Biometry: principles and practice of statistics in biological research, 2nd edn. Freeman Press, San Francisco

Standing, J., Hooper, I. R., Costlow, J. D. (1.984). Inhibition and

This article was submitted to the editor induction of barnacle settlement by natural products present in octocorals. J. chem. Ecol. 10: 823-835

Targett, N. M., Bishop, S. S., McConnell, O. J., Yoder, J. A (1983). Antifouling agents against the benthic marine diatom Navicula salinicola: homarine from the gorgonian Leptogorgia virgulata and $L$. setacea and analogs. J. chem. ECol. 9: 817-829

Wahle, C. M. (1980). Detection, pursuit, and overgrowth of tropical gorgonians by milleporid hydrocorals: Perseus and Medusa revisited. Science 209: 689-691

Wahle, C. M. (1983a). Regeneration of injuries among Jamaican gorgonians: the roles of colony physiology and environment. Biol. Bull. mar. biol. Lab., Woods Hole 165: 778-790

Wahle, C. M. (1983b). The role of age, size, and injury in sexual reproduction among Jamaican gorgonians. A.m. Zool. 23: 961

Wahle, C. M. (1985). Habitat-related patterns of injury and mortality among Jamaica gorgonians. Bull. mar. Sci. 37: 905-927

Manuscript first received: April 26, 1989

Revised version accepted. December 29, 1989 